\title{
An Economic Estimation of Capsicum Production in Shajapur District of Madhya Pradesh, India
}

\author{
Pradeep Kumar Patidar ${ }^{1 *}$, P. R. Pandy ${ }^{1}$, J. K. Gupta ${ }^{1}$ and Trapti Pawaiya ${ }^{2}$ \\ ${ }^{1}$ (Agril. Economics) Department of Transfer of Technology, \\ Faculty of Agriculture, MGCGV, Chitrakoot, Satna (M.P.), India \\ ${ }^{2}$ Department of Agriculture Economics and Farm Management, \\ RVSKVV, College of Agriculture, Indore (M.P.), India \\ *Corresponding author
}

\section{A B S T R A C T}

\begin{tabular}{|l|}
\hline Ke y w or d s \\
$\begin{array}{l}\text { Solanaceae family, } \\
\text { green pepper, } \\
\text { cultivation }\end{array}$ \\
\hline Article Info \\
\hline $\begin{array}{l}\text { Accepted: } \\
\text { 18 May } 2020 \\
\text { Available Online: } \\
\text { 10 June } 2020\end{array}$ \\
\hline
\end{tabular}

Capsicum or Bell pepper or Hot pepper (Capsicum annum L.) is a crop of Solanaceae family and its genus is Capsicum. It is also known as green pepper or shimla mirch. Present investigation was conducted in Shajjapur District of M.P. A multistage stratified random sampling technique was adopted to selection of sample. The study showed that on an average, cost of cultivation per hectare of capsicum crop on overall basis was found to be cost A1 that is paid out cost Rs.53318 followed by Rs.56624.32 (cost B1), Rs.10015.50 (cost B2), Rs.64383.98 (cost C1), Rs.107775.16 (cost C2) and Rs.118552.68 (cost C3) respectively. The average yield was found to be 110.08 quintal per hectare. The net income is the real income realized by capsicum growers and it was found to be on an average of Rs.141794.40 per hectare, and B.C. ratio on an average of 2.19 as B.C. ratio in capsicum production. The major constraints which got higher frequency value than the average value were "high cost of seed" reported by $\left(83.33 \%\right.$, rank $\left.I^{\text {st }}\right)$ followed by "absence of remunerative price" reported by $\left(83.33 \%\right.$, rank $\left.\mathrm{II}^{\text {nd }}\right)$, "lack of desire variety" reported by $\left(82.22 \%\right.$, rank III $\left.^{\text {rd }}\right)$ and"lack od knowledge of plant protection measures" reported by $\left(78.88 \%\right.$, rank $\left.I^{\text {th }}\right)$ respectively.

\section{Introduction}

Capsicum or Bell pepper or hot pepper (Capsicum annum L.) is a crop of Solanaceae family and its genus is Capsicum. It is also known as green pepper or shimla mirch. Capsicum is one of the most important commercial crops of India. It is grown almost throughout the country. There are more than 400 different varieties of chillies found all over the world. It is also called as hot pepper, cayenne pepper, sweet pepper, bell pepper, etc. to Its botanical name is "Capsicum annuum".

Chillies are rich in vitamins, especially in vitamin $\mathrm{A}$ and $\mathrm{C}$. India contributes one fourth of world production of capsicum with an average annual production of 0.9 MT from an area of 0.885 million hectares [International Journal of Farm Sciences 6(1)], While M.P. contributes 33.84 million tones which shares 
about $11.73 \%$ of total area( National Horticulture Board). Madhya Pradesh is the producer of Capsicum in India and contributes about $7 \%$ to the total area under chilli.

The main objectives of this study includes, to estimate cost of cultivation of capsicum in different categories of respondents. And also to identify constraints in capsicum production.

\section{Materials and Methods}

A multistage stratified random sampling technique was adopted to select the block, villages and the respondents, market and different functionaries involved in capsicum marketing in Shajapur district of Madhya Pradesh. The details of the sampling techniques at various stages are given as under:

\section{Selection of block}

The Shajapur district of Madhya Pradesh. was selected purposively because capsicum is the main vegetable crop of the district. There are 5 blocks in the Shajapur. Thus, from 5 blocks, Shujalpur block was selected purposively due to higher area and production of capsicum cultivation.

\section{Selection of the villages}

A list of selected villages coming under the study areas was prepared and three villages namely (Barchha, Mewasa and Sajod) from Shujalpur block was selected on the basis of highest production and productivity of capsicum crop.

\section{Selection of farmers}

A list of selected farmers from the selected villages were prepared as per their size of holding and farmers categorized under three category viz. Small (Up to 2 ha), Medium (2 to $4 \mathrm{ha}$ ) and Large (above 4 to $10 \mathrm{ha}$ ). From each group 30 farmers were selected by random sampling basis hence, the sample was consisted of 90 farmers.

\section{Collection of data}

\section{Land use pattern}

Table No. 1 shows that the average size of land holdings ranged from 1.86 ha. to 8.79 ha. on different size of farm with an average of 4.66 ha. on sample respondent. Of the total net cultivated area, 94.27 per cent was available for cultivation on sample respondents with marginal variations in small and medium size groups.

The minimum area under net sown was observed on large size group (93.06\%) against maximum in case of small group $(97.31 \%)$. Thus, proportionate area under cultivation revealed inverse relation with the farm size. The net irrigated area was 76.56 to 79.57 per cent of total area on sample respondent and the uncultivated area was 2.69 to 6.94 per cent in different size of groups.

\section{Cost of cultivation of capsicum}

The data of Table No. 2 revealed that irrespective of the farm size of holdings, the total cost of cultivation of capsicum of sample farms has been observed on overall average basis as Rs.118552.68 per hectare, total variable cost was $51.52 \%$ and the share of material input cost was maximum and found to be $34.12 \%$ followed by labor cost $17.40 \%$, interest on working capital $1.03 \%$ and fixed cost $39.38 \%$.

Rental value of land $36.60 \%$ and interest on fixed capital $0.76 \%$, respectively. The share of machine power and bullock power were $4.20 \%$ and $0.27 \%$ respectively. 


\section{Aggregate cost of capsicum cultivation}

From Table No. 3 it has been observed that the cost of cultivation of capsicum showed that on an average cost, of cultivation per hectare of capsicum crop on overall basis was found to be cost A1 that was paid out cost Rs.53318 followed by Rs.56624.32 (cost B1), Rs.100015.50 (cost B2), Rs.64383.98 (cost C1), Rs.107775.16 (cost C2) and Rs.118552.68 (cost C3) respectively.

\section{Productivity of capsicum production}

From Table No. 4 it has been observed that the average yield was found to be 110.08 quintal per hectare. Data showed that the average yield on different size of holdings was found to be maximum 115.50 quintal per hectare on small size of holding followed by 109.25 quintal per hectare on medium size of holding and 105.50 quintal per hectare on large size of holding.

\section{Profitability from capsicum cultivation}

Gross income per hectare of capsicum production received variation in different size group. This was due to different quantity of yield per unit area and market price received on the basis of quality of crop, place of marketing and time of disposal.

The overall gross income per, hectare of capsicum was found to be Rs. 260347.08 per hectare. The maximum gross return of capsicum cultivation was realized by small capsicum growers Rs.273157.50 per hectare followed by medium capsicum growers Rs.158376.25 per hectare and large capsicum growers Rs.249507.50 per hectare.

The net income is the real income realized by capsicum growers and it was found to be an average of Rs.141794.40 per hectare. The maximum net return of capsicum cultivation was realized by small capsicum growers Rs.149394.17 per hectare followed by medium capsicum growers Rs.140807.02 per hectare and large capsicum growers Rs.135182.02 per hectare.

Table.1 Average land use pattern of sample farms (in ha)

\begin{tabular}{|l|l|c|c|c|c|}
\hline S. & Particulars & \multicolumn{3}{|c|}{ Size group } & Average \\
\cline { 3 - 6 } No. & & Small & Medium & Large & \\
\hline $\mathbf{1}$ & Land holding & 1.86 & 3.32 & 8.79 & 4.66 \\
& & $(100)$ & $(100)$ & $(100)$ & $(100)$ \\
\hline $\mathbf{2}$ & Net Cultivated area area & 1.81 & 3.18 & 8.18 & 4.39 \\
& & $(97.31)$ & $(95.78)$ & $(93.05)$ & $(94.27)$ \\
\hline $\mathbf{3}$ & Uncultivated land & 0.05 & 0.14 & 0.61 & 0.27 \\
& & $(2.69)$ & $(4.22)$ & $(6.94)$ & $(5.73)$ \\
\hline $\mathbf{4}$ & Net Irrigated area & 1.48 & 2.59 & 6.73 & 3.91 \\
& & $(79.57)$ & $(78.01)$ & $(76.56)$ & $(83.97)$ \\
\hline $\mathbf{5}$ & Double cropped area & 1.81 & 3.00 & 7.26 & 4.33 \\
& & $(92.18)$ & $(87.07)$ & $(74.54)$ & $(80.49)$ \\
\hline $\mathbf{6}$ & Grossed cropped area & 3.55 & 6.18 & 15.44 & 8.97 \\
\hline $\mathbf{7}$ & Cropping Intensity (\%) & 196.13 & 194.37 & 188.75 & 193.08 \\
\hline
\end{tabular}

(Figures in brackets indicate percentage to the total) 
Table.2 Cost of cultivation of capsicum on different size of holding. (Rs./ha)

\begin{tabular}{|c|c|c|c|c|c|}
\hline \multirow{2}{*}{$\begin{array}{l}\text { S. } \\
\text { No. }\end{array}$} & \multirow[t]{2}{*}{ Cost item } & \multicolumn{4}{|c|}{ Size of farm } \\
\hline & & Small & Medium & Large & Average \\
\hline \multirow[t]{6}{*}{$\mathbf{A}$} & \multicolumn{5}{|c|}{ Labour cost } \\
\hline & Family human labour & $\begin{array}{l}10675 \\
(8.63)\end{array}$ & $\begin{array}{c}8018 \\
(6.82)\end{array}$ & $\begin{array}{c}4586 \\
(4.01)\end{array}$ & $\begin{array}{c}7759.67 \\
(6.49)\end{array}$ \\
\hline & Hired human labour & $\begin{array}{l}5360 \\
(4.33)\end{array}$ & $\begin{array}{r}6896 \\
(5.86)\end{array}$ & $\begin{array}{l}10469 \\
(9.16)\end{array}$ & $\begin{array}{l}7574 \\
(6.45)\end{array}$ \\
\hline & Bullock labour & $\begin{array}{c}450 \\
(0.36)\end{array}$ & $\begin{array}{c}400 \\
(0.34)\end{array}$ & $\begin{array}{c}125 \\
(0.11)\end{array}$ & $\begin{array}{c}325 \\
(0.27)\end{array}$ \\
\hline & Machine Power & $\begin{array}{l}5045 \\
(4.08)\end{array}$ & $\begin{array}{c}5010 \\
(4.26)\end{array}$ & $\begin{array}{l}4865 \\
(4.26)\end{array}$ & $\begin{array}{c}4973.33 \\
(4.20)\end{array}$ \\
\hline & Total labour cost & $\begin{array}{l}21530 \\
(17.40)\end{array}$ & $\begin{array}{c}20321 \\
(17.28)\end{array}$ & $\begin{array}{l}20045 \\
(17.53)\end{array}$ & $\begin{array}{c}20632 \\
(17.40)\end{array}$ \\
\hline \multirow[t]{6}{*}{ B } & \multicolumn{5}{|l|}{ Material Cost } \\
\hline & Seed cost & $\begin{array}{c}18590 \\
(15.02)\end{array}$ & $\begin{array}{c}18435 \\
(15.68)\end{array}$ & $\begin{array}{c}18175 \\
(15.90)\end{array}$ & $\begin{array}{c}18400 \\
(15.53)\end{array}$ \\
\hline & Fertilizer \& manure & $\begin{array}{l}8200 \\
(6.63)\end{array}$ & $\begin{array}{l}7420 \\
(6.31)\end{array}$ & $\begin{array}{c}7323 \\
(6.41)\end{array}$ & $\begin{array}{c}7647.67 \\
(6.45)\end{array}$ \\
\hline & Irrigation charges & $\begin{array}{l}2535 \\
(2.85)\end{array}$ & $\begin{array}{l}3240 \\
(2.76)\end{array}$ & $\begin{array}{c}3115 \\
(2.72)\end{array}$ & $\begin{array}{c}3293.33 \\
(2.78)\end{array}$ \\
\hline & Plant protection measures & $\begin{array}{l}11586 \\
(9.36)\end{array}$ & $\begin{array}{l}11142 \\
(6.48)\end{array}$ & $\begin{array}{l}10586 \\
(9.26)\end{array}$ & $\begin{array}{c}11104.67 \\
(9.37)\end{array}$ \\
\hline & Total material cost & $\begin{array}{l}41901 \\
(33.86)\end{array}$ & $\begin{array}{l}40237 \\
(34.22)\end{array}$ & $\begin{array}{c}39199 \\
(34.29)\end{array}$ & $\begin{array}{c}40445.67 \\
(34.12)\end{array}$ \\
\hline \multirow[t]{9}{*}{$\mathbf{C}$} & \multicolumn{5}{|l|}{ Fixed cost } \\
\hline & Interest on working capital & $\begin{array}{c}1268.62 \\
(1.03)\end{array}$ & $\begin{array}{c}1211.16 \\
(1.03)\end{array}$ & $\begin{array}{c}1029.91 \\
(1.04)\end{array}$ & $\begin{array}{c}1149.80 \\
(1.03)\end{array}$ \\
\hline & Taxes / land revenue & $\begin{array}{c}30 \\
(0.2)\end{array}$ & $\begin{array}{c}30 \\
(0.3)\end{array}$ & $\begin{array}{c}30 \\
(0.3)\end{array}$ & $\begin{array}{c}30 \\
(0.3)\end{array}$ \\
\hline & Depreciation & $\begin{array}{c}1287.89 \\
(1.04)\end{array}$ & $\begin{array}{c}1131.59 \\
(0.96)\end{array}$ & $\begin{array}{c}1029.91 \\
(0.90)\end{array}$ & $\begin{array}{c}1149.80 \\
(0.97)\end{array}$ \\
\hline & Rental value of own land & $\begin{array}{c}45526.25 \\
(36.78)\end{array}$ & $\begin{array}{c}43062.71 \\
(36.63)\end{array}$ & $\begin{array}{c}41584.58 \\
(36.37)\end{array}$ & $\begin{array}{c}43391.18 \\
(36.60)\end{array}$ \\
\hline & Interest on fixed capital & $\begin{array}{l}968.36 \\
(0.78)\end{array}$ & $\begin{array}{l}887.66 \\
(0.76)\end{array}$ & $\begin{array}{l}858.88 \\
(0.75)\end{array}$ & $\begin{array}{l}904.97 \\
(0.76)\end{array}$ \\
\hline & Total fixed cost & $\begin{array}{c}49081.12 \\
(39.66)\end{array}$ & $\begin{array}{c}46323.12 \\
(39.40)\end{array}$ & $\begin{array}{c}44688.25 \\
(39.09)\end{array}$ & $\begin{array}{c}46697.50 \\
(39.38)\end{array}$ \\
\hline & Total cost $\left(\operatorname{cost} C_{2}\right)$ & $\begin{array}{c}112512.12 \\
(90.91)\end{array}$ & $\begin{array}{c}106881.12 \\
(90.91)\end{array}$ & $\begin{array}{c}103932.25 \\
(90.91)\end{array}$ & $\begin{array}{c}107775.16 \\
(90.91)\end{array}$ \\
\hline & Cost $C_{3}$ & $\begin{array}{c}123763.33 \\
(100)\end{array}$ & $\begin{array}{c}117569.23 \\
(100)\end{array}$ & $\begin{array}{c}114325.48 \\
(100)\end{array}$ & $\begin{array}{c}118552.68 \\
(100)\end{array}$ \\
\hline
\end{tabular}

(Figures in parentheses show percentage to total cost) 
Table.3 Aggregate cost of capsicum on different size of holdings (Rs./ha)

\begin{tabular}{|l|c|c|c|c|}
\hline \multirow{2}{*}{ Particulars } & \multicolumn{4}{|c|}{ Size of farm } \\
\cline { 2 - 5 } & Small & Medium & Large & Overall \\
\hline Cost A1/A2 & 52756.00 & 52540.00 & 54658.00 & 53318.00 \\
\hline Cost B1 & 56310.87 & 55800.41 & 57761.67 & 56624.32 \\
\hline Cost B2 & 101837.12 & 98863.12 & 99346.25 & 100015.50 \\
\hline Cost C1 & 66985.87 & 63818.41 & 62347.67 & 64383.98 \\
\hline Cost C2 & 112512.12 & 106881.12 & 103932.25 & 107775.16 \\
\hline Cost C3 & 123763.33 & 117569.23 & 114325.48 & 118552.68 \\
\hline
\end{tabular}

Table.4 Productivity of capsicum in on different size of holding (q/ha)

\begin{tabular}{|l|c|c|c|c|}
\hline Particulars & \multicolumn{4}{|c|}{ Size group } \\
\cline { 2 - 5 } & Small & Medium & Large & Overall \\
\hline Production (qtl./ha) & 115.5 & 109.25 & 105.50 & 110.08 \\
\hline value of product (Rs./ha) @ Rs.2365/q. & 273157.5 & 258376.25 & 249507.50 & 260347.08 \\
\hline
\end{tabular}

Table.5 Profitability of capsicum on different size of holding (Rs./ha.)

\begin{tabular}{|l|c|c|c|c|}
\hline \multirow{2}{*}{ Particulars } & \multicolumn{4}{|c|}{ Size group } \\
\cline { 2 - 5 } & Small & Medium & Large & Overall \\
\hline Total cost (Cost C3) & 123763.33 & 117569.23 & 114325.48 & 118552.68 \\
\hline Gross income & 273157.50 & 258376.25 & 249507.50 & 260347.08 \\
\hline Net farm income & 149394.17 & 140807.02 & 135182.02 & 141794.40 \\
\hline Family labour income & 171320.38 & 159513.13 & 150161.25 & 160331.59 \\
\hline Farm business income & 220401.50 & 205836.25 & 194849.50 & 207029.08 \\
\hline Farm investment income & 195888.78 & 184757.39 & 177625.48 & 186090.55 \\
\hline Cost of production (Rs./q) & 1071.54 & 1076.15 & 1083.65 & 1077.12 \\
\hline B:C ratio & $1: 2.20$ & $1: 2.19$ & $1: 2.18$ & $1: 2.19$ \\
\hline
\end{tabular}

Table.6 Constraints faced by the sample farmers in production of capsicum

\begin{tabular}{|c|c|c|c|c|c|c|}
\hline S. No. & Constraints relating to & $\begin{array}{c}\text { Small } \\
(\mathrm{N}=\mathbf{3 0})\end{array}$ & $\begin{array}{c}\text { Medium } \\
(\mathrm{N}=30)\end{array}$ & $\begin{array}{c}\text { Large } \\
(\mathrm{N}=\mathbf{3 0})\end{array}$ & $\begin{array}{c}\text { Total } \\
(\mathbf{N}=90)\end{array}$ & Ranking \\
\hline 1 & Lack of capital & $\begin{array}{c}27 \\
(90)\end{array}$ & $\begin{array}{c}18 \\
(60)\end{array}$ & $\begin{array}{c}16 \\
(53.33)\end{array}$ & $\begin{array}{c}61 \\
(67.77)\end{array}$ & VI \\
\hline 2 & High cost of seed & $\begin{array}{c}26 \\
(86.66)\end{array}$ & $\begin{array}{c}24 \\
(80)\end{array}$ & $\begin{array}{c}21 \\
(70)\end{array}$ & $\begin{array}{c}78.88 \\
(83.33)\end{array}$ & I \\
\hline 3 & Unavailability of skill labour & $\begin{array}{c}24 \\
4(80)\end{array}$ & $\begin{array}{c}21 \\
(70)\end{array}$ & $\begin{array}{c}19 \\
(63.33)\end{array}$ & $\begin{array}{c}64 \\
(71.11)\end{array}$ & $\mathbf{V}$ \\
\hline 4 & Absence of remunerative price & $\begin{array}{c}27 \\
(90)\end{array}$ & $\begin{array}{c}25 \\
(83.33)\end{array}$ & $\begin{array}{c}23 \\
(76.66)\end{array}$ & $\begin{array}{c}75 \\
(83.33)\end{array}$ & II \\
\hline 5 & Lack of desired variety & $\begin{array}{c}27 \\
(90)\end{array}$ & $\begin{array}{c}24 \\
(80)\end{array}$ & $\begin{array}{c}23 \\
(76.66)\end{array}$ & $\begin{array}{c}74 \\
(82.22)\end{array}$ & III \\
\hline 6 & $\begin{array}{l}\text { Lack of knowledge of plant } \\
\text { protection measure }\end{array}$ & $\begin{array}{c}26 \\
(86.66)\end{array}$ & $\begin{array}{c}23 \\
(76.66)\end{array}$ & $\begin{array}{c}22 \\
(\mathbf{7 3 . 3 3})\end{array}$ & $\begin{array}{c}71 \\
(78.88)\end{array}$ & IV \\
\hline
\end{tabular}


The trend of net income revealed that it decreased with increase in size of holding. The other profitability measures reveal that on an average, the capsicum growers realized Rs.160331.59 per farm as family labour income, Rs.207029.08 per farm as farm business income. The B.C. ratio determines the return per rupee investment. Data revealed that the capsicum growers realized on an average of 2.19 as B.C. ratio in capsicum production.

The B.C. ratio was found to be varied in different size of holding and it was maximum 2.20 in small size group followed by 2.19 in medium size group and 1.18 in large size of capsicum growers. This indicates that the B.C. ratio of capsicum cultivation was found to increase with increase in size of holding.

\section{Constraints of production of capsicum}

The study regarding constraints faced by farmers in Production of capsicum among the all six constraints the major constraints which got higher frequency value than the average value were "high cost of seed" reported by $\left(83.33 \%\right.$, rank $\left.\mathrm{I}^{\mathrm{st}}\right)$ followed by "absence of remunerative price " reported by $(83.33 \%$, rank $\mathrm{II}^{\text {nd }}$ ), "lack of desire variety" reported by $\left(82.22 \%\right.$, rank III $\left.^{\text {rd }}\right)$, "lack od knowledge of plant protection measures" reported by $\left(78.88 \%\right.$, rank $\left.\mathrm{IV}^{\text {th }}\right)$, "unavailability of skill labour" reported by $(71.11 \%$, rank Vth) and "lack of capital" reported by (67.77\%, rank VIth) respectively.

The data on cost of cultivation of capsicum shows that on an average, cost of cultivation per hectare of capsicum crop on overall basis was found to be cost A1 that is paid out cost Rs.53318 followed by Rs.56624.32 (cost B1), Rs.10015.50 (cost B2), Rs.64383.98 (cost C1), Rs.107775.16 (cost C2) and Rs.118552.68 (cost C3) respectively. The average yield was found to be 110.08 quintal per hectare. The net income is the real income realized by capsicum growers and it was found to be on an average of Rs.141794.40 per hectare.

Data revealed that the B.C. ratio determines the return per rupee investment. Data that the capsicum growers realized was on an average of 2.19 as B.C. ratio in capsicum production.

\section{References}

Ali Q, Ashfaq M and Khan MTI. 2016. An Economic Analysis Of Off-Season Capsicum/Bell Pepper Production In Punjab, Pakistan. Arpn Journal of Agricultural and Biological Science Vol. 11, No. 11, November 2016

Deore SG, Pawar PP and Pulate SL. 2015. Economics of marketing of Green Chilli in Western Maharashtra. Internat. J. Appl. Soc. Sci., 2 (3\&4) : 84.

Elayutham LKV and Damodaran K. 2015. Growth Rate of Chilli Production in Guntur District of Andhra Pradesh. International Journal of Research in Humanities and Social Studies, Volume 2, Issue 11, November 2015, PP 1-5.

Geetha R and Selvarani K. 2017. A study of chilli production and export from india, ijariie-issn(O)-239543964025 , Vol-3 issue-2 2017.

Kumar Parveen, Chauhan RS and Grover RK. 2016. Economic analysis of capsicum cultivation under polyhouse and open field conditions in Haryana. International Journal of Farm Sciences 6(1) : 96-100, 2016.

Khan MTI, Ali, Q Ashfaq M and Waseem M.2017 Economic Analysis Of Open field Chilli (Capsicum Annuum L.) Production In Punjab, Pakistan. Journal of experimental Biology and Agricultural Sciences, February - 2017; Volume - 5(1).

Meena NK, Gawade BB, Dhage Anil Mohan, 
Shinde HR, Kumar Rajesh And Gurjar GN. 2017. A study of marketing of green chilli in kolhapur district of Maharashtra, International Journal of Agriculture Sciences ISSN: 09753710\&E- ISSN: 0975-

Rajur BC and Patil BL. 2015. Price spread, marketing costs and margins of chilli in Karnataka state Karnataka J. Agric. Sci., 28(3): (364-368) 2015.

Sashimatsung Giribabu 2015. Economic analysis on production and marketing of Chilli in Mokokchung District of Nagaland An International Peerreviewed Journal Vol.13.
Senthilkumar S, Ashok KR, Chinnadurai M, and Ramanathan SP. 2018. An Economic Analysis of Capsicum Production under Protected Cultivation in North West Region of Tamil Nadu, India. International Journal of Current Microbiology and Applied Sciences 7(6): 2276-2283, ISSN: 23197706 Volume 7 Number 06 (2018). Velayutham LK, Damodaran K. 2015. Growth Rate of Chilli Production in Guntur District of Andhra Pradesh International Journal of Research in Humanities and Social Studies Volume 2, PP 1-5.

\section{How to cite this article:}

Pradeep Kumar Patidar, P. R. Pandy, J. K. Gupta and Trapti Pawaiya. 2020. An Economic Estimation of Capsicum Production in Shajapur District of Madhya Pradesh, India. Int.J.Curr.Microbiol.App.Sci. 9(06): 1796-1802. doi: https://doi.org/10.20546/ijcmas.2020.906.224 